\begin{tabular}{|} 
Ambiente \& Água - An Interdisciplinary Journal of Applied Science \\
ISSN 1980-993X - doi:10.4136/1980-993X \\
www.ambi-agua.net \\
E-mail: ambi.agua@gmail.com
\end{tabular}

\title{
Soil attributes as indicators of the stabilization process of erosion in gullies at different formation stages in the southeast region of Brazil
}

\author{
ARTICLES doi:10.4136/ambi-agua.2632
}

Received: 22 Aug. 2020; Accepted: 24 May 2021

\author{
Cristiane Figueira da Silva1(iD; Marcos Gervasio Pereira ${ }^{2 *}$; \\ Luiz Alberto da Silva Rodrigues Pinto ${ }^{3 D}$; Sabrina Aparecida Teodoro4 ${ }^{(D}$; \\ Marcelo Antoniol Fontes ${ }^{5}$; ; João Henrique Gaia-Gomes ${ }^{2}$; \\ Eliane Maria Ribeiro da Silva ${ }^{6}$ (D)
}

\footnotetext{
${ }^{1}$ Instituto de Florestas. Programa de Pós-Graduação em Ciências Ambientais e Florestais. Universidade Federal Rural do Rio de Janeiro (UFRRJ), BR 465, Km 7, CEP: 23890-000, Seropédica, RJ, Brazil.

E-mail: cfigueirasilva@yahoo.com.br

${ }^{2}$ Instituto de Agronomia. Departamento de Solos. Universidade Federal Rural do Rio de Janeiro, BR 465, Km 7, CEP: 23890-000, Seropédica, RJ, Brazil. E-mail: gaia.gomes.pgeaamb@gmail.com

${ }^{3}$ Instituto de Agronomia. Programa de Pós-Graduação em Agronomia. Departamento de Solos. Universidade Federal Rural do Rio de Janeiro, BR 465, Km 7, CEP: 23890-000, Seropédica, RJ, Brazil. E-mail: 1_arodrigues@yahoo.com.br

${ }^{4}$ Universidade Federal de Lavras (UFLA), Avenida Doutor Sílvio Menicucci, s/n, CEP: 37200-900, Aquenta Sol, Lavras, MG, Brazil. E-mail: sabrinateo.teo@gmail.com

${ }^{5}$ Centro Nacional de Pesquisa de Agrobiologia. Laboratório de Leguminosas Florestais. Empresa Brasileira de Pesquisa Agropecuária (EMBRAPA), BR 465, Km 7, CEP: 23890-000, Seropédica, RJ,

Brazil. E-mail: marcelo.fontes@yahoo.com.br

${ }^{6}$ Centro Nacional de Pesquisa de Agrobiologia. Laboratório de Micorrizas. Empresa Brasileira de Pesquisa Agropecuária (EMBRAPA), BR 465, Km 7, CEP: 23890-000, Seropédica, RJ, Brazil.

E-mail: eliane.silva@embrapa.br

*Corresponding author. E-mail: mgervasiopereira01@gmail.com
}

\begin{abstract}
Water erosion is one of the main forms of soil degradation, causing economic, environmental, and social damage. This study evaluated the effects of different formation stages of gullies (initial - IG; juvenile- JG; mature - MG; and senile - SG) on the chemical, organic carbon and microbiological attributes of soil, using a secondary forest (SF) and two areas of pasture as references in the "Mar de Morros" environment of the Brazilian Atlantic Forest biome. Soil samples (depth $0-0.05 \mathrm{~m}$ ) were collected at the end of the rainy and dry seasons. Gullies in different stages of formation promote a decrease in soil fertility and modification of microbiological attributes, particularly when compared with secondary forest areas. Reductions of over $60 \%$ in total organic carbon (TOC), oxidizable organic carbon (POXC), FDA activity, $\beta$-glycosidase, acid phosphatase, $\mathrm{C}$ and $\mathrm{N}$ from microbial biomass, basal soil respiration (BSR) and glomalin-related soil protein (GRSP) were observed in gullies in early (IG) and intermediate (JG and MG) stages when compared to SF. It was found that the effect of erosion on soil chemical and microbiological attributes is more intense in gullies in the initial and intermediate stages compared with those in the senile stage (SG). Using multivariate PCA, the microbiological and chemical attributes of the soil are discriminated between gullies with distinct formation stages. Chemical attributes, TOC, POXC, FDA activity, $\beta$-glycosidase, acid phosphatase, MBC and MBN, BSR, and GRSP are good indicators for evaluating the process of erosion stabilization in gullies.
\end{abstract}

This is an Open Access article distributed under the terms of the Creative Commons Attribution License, which permits unrestricted use, distribution, and reproduction in any medium, provided the original work is properly cited. 
Keywords: enzymatic activity, glomalin, oxisols, soil microbial biomass, soil organic carbon, water erosion.

\section{Atributos do solo como indicadores do processo de estabilização da erosão em voçorocas em diferentes estágios de formação na região sudeste do Brasil}

\section{RESUMO}

A erosão hídrica é uma das principais formas de degradação do solo, causando danos econômicos, ambientais e sociais. O objetivo deste estudo foi avaliar o efeito de diferentes estágios de formação de voçorocas (inicial - IG; juvenil - JG; maduro - MG; e senil - SG) nos atributos químicos, matéria orgânica e microbiológicos do solo, utilizando uma floresta secundária (SF) e duas áreas de pastagem como referência no ambiente "Mar de Morros" do bioma Mata Atlântica brasileira. Amostras de solo (profundidade 0-0,05 m) foram coletadas no final das estações chuvosa e seca. As voçorocas em diferentes estágios de formação promoveram diminuição da fertilidade do solo e modificação dos atributos microbiológicos, principalmente quando comparados com a área de floresta secundária. Reduções de mais de $60 \%$ no carbono orgânico total (TOC), carbono orgânico oxidável (POXC), atividade da FDA, $\beta$-glicosidase, fosfatase ácida, C (MBC) e N (MBN) da biomassa microbiana, respiração basal do solo (BSR) e proteína do solo relacionada à glomalina (GRSP) foram observados em voçorocas nos estágios inicial (IG) e intermediário (JG e MG) quando comparados ao SF. Verificou-se que o efeito da erosão sobre os atributos químicos e microbiológicos do solo é mais intenso em voçorocas nos estágios inicial e intermediário em comparação com ao senil (SG). Usando a multivariada PCA, os atributos microbiológicos e químicos do solo discriminaram as voçorocas com distintos estágios de formação. Os atributos químicos, TOC, POXC, atividade FDA, $\beta$-glicosidase, fosfatase ácida, MBC and MBN, SBR e GRSP são bons indicadores para avaliar o processo de estabilização da erosão em voçorocas.

Palavras-chave: atividade enzimática, biomassa microbiana do solo, carbono orgânico do solo, erosão hídrica, glomalina, latossolos.

\section{INTRODUCTION}

The Atlantic Forest biome has been subjected to strong anthropic pressure, to include intense deforestation since the discovery of Brazil (SOS Mata Atlântica, 2018). This region is characterized by a variable relief, with flat areas and many valleys and hills. Removal of the original forest intensified erosion and reduced plant-growth capacity (Landeros-Sánchez et al., 2009). In the state of Rio de Janeiro, particularly in the Pinheiral area, there has been a high degree of erosion due to uneven relief, removal of vegetation cover, and inappropriate practices of land use and management in agricultural crops and, mainly, pastures. A study carried out by the Paraíba do Sul River Basin Committee (CEIVAP) indicates that the stretch between the sediment stations of Volta Redonda and Barra do Piraí, in which lies the municipality of Pinheiral, has the second largest specific sediment production $\left(588.8 \mathrm{Mg} \mathrm{km}^{-2}\right.$ year $^{-1}$ ) (CEIVAP, 2006). Large portions of the soils have a high erosion potential (Gaia-Gomes et al., 2018; 2020), and high levels of rainfall increase water erosion. Water erosion is one of the main forms of soil degradation, causing economic, environmental, and social damage. This type of erosion leads to the emergence of gullies, which are formed by the processes of soil runoff and high soil loss (Vanwalleghem et al., 2005).

Gullies represent the most severe form of erosion and can be classified into their formation stages (initial, juvenile, mature, and senile) based on morphological characteristics. These 
include the development of channels, their cross-section, bed profile, walls, branches, and ducts (Oka-Fiore and Soares, 1976), and the presence or absence of vegetation. Although some studies have characterized the formation stages of gullies (Oka-Fiore and Soares, 1976; Dobek et al., 2011), few have evaluated soil attributes (physical, chemical, and biological) in these environments (Machado et al., 2010; Gomide et al., 2011; Gaia-Gomes et al., 2018; 2020), especially in relation to their microbiological attributes.

Soil attributes, such as microbial biomass and enzymatic activity, are influenced by many factors and have been suggested as appropriate indicators for assessing soil quality (Maurya $e t$ al., 2020; Tiwari et al., 2019; Zhou et al., 2018). Estimates of soil microbial biomass may indicate changes in the total organic matter of the soil long before changes in total soil $\mathrm{C}$ and $\mathrm{N}$ levels are detectable (Babur and Dindaroglu, 2020). Moreover, this can provide an index of soil fertility, because it represents an important labile reservoir of soil nutrients, playing an active role in preventing nutrient loss (Yang et al., 2010).

The enzymatic activity of the soil, in turn, plays a critical role in the cycles of soil elements and how they are synthesized by organisms. The conditions that favor microbial activity, such as the presence of vegetation (rhizosphere), also lead to higher enzyme activity (Zhang et al., 2018). Enzymes participate in the catabolism of organic and mineral soil components, and their activity correlates with organic matter, physical and chemical properties, and with the microbial biomass (Maurya et al., 2020; Tiwari et al., 2019; Yuan and Yue, 2012).

The soil microbial community has long been recognized for its involvement in the biogeochemical transformation of carbon, nitrogen, phosphorus, and sulfur in soil, which directly influences the structure and productivity of the plant community (Elliot et al., 2015). Furthermore, bacteria and fungi promote improvements in soil structure that favor aggregation and porosity (Hashim et al., 2020; Muchane et al., 2018). For example, when associated with plant roots, arbuscular mycorrhizal fungi (AMF) improve soil aggregation via hyphae and the production of glomalin (Parihar et al., 2020). This glycoprotein is important for the aggregation and storage of soil carbon and nitrogen (Sekaran et al., 2021, Wang et al., 2017). Glomalin is positively correlated with the stability of aggregates and carbon. The response of these components to changes in land use suggest that glomalin may be used as an indicator of ecosystem degradation/recovery (Liu et al., 2020).

The hypothesis of this study was that the chemical attributes, organic carbon, and soil microbiological attributes change in gullies at different stages of formation (initial, juvenile, mature, and senile) and can be used as indicators of erosion stabilization. Thus, the objective of this study was to evaluate the effect of gully formation stage (initial, juvenile, mature, and senile) on soil chemical, organic carbon, and soil microbiological attributes using a secondary forest area and two areas of regenerating pasture (initial and medium stage) as references in "Mar de Morros" in the Atlantic Forest biome, Brazil.

\section{MATERIAL AND METHODS}

The study was conducted in the municipality of Pinheiral - RJ, in the Sub-basin of the Ribeirão Cachimbal, which is located in the region of the Middle Paraíba Fluminense and comprises the hydrographic basin of the Paraíba do Sul River (Figure 1). It is located between latitudes $22^{\circ} 29^{\prime} 03^{\prime \prime} \mathrm{S}$ and $22^{\circ} 35^{\prime} 27^{\prime \prime} \mathrm{S}$, and longitudes $43^{\circ} 54^{\prime} 49^{\prime \prime} \mathrm{W}$ and $44^{\circ} 04^{\prime} 05^{\prime \prime} \mathrm{W}$. The climate of the region, according to Köppen (1936) is Am, with a tropical rainy climate, monsoon, and dry winter. The area forms part of the ecological area of the Atlantic Forest, whose original vegetation is identified as Baixo Montana Atlantic Rainforest, and is characteristic of areas with altitudes of 300-800 m. The region presents various forms of relief with different degrees of dissection. The altitude varies from $360 \mathrm{~m}$ in the large floodplain of Paraíba do Sul, at the mouth of the Cachimbal Stream, to $720 \mathrm{~m}$ in the Arrozal mountain range in the south of the Cachimbal River Basin (Machado et al., 2010). In the area covered by the 
Cachimbal Stream, hillsides with varied slopes predominate; $35 \%$ are classified as strong wavy, $28 \%$ wavy, $17 \%$ soft wavy, $10.5 \%$ flat, $9 \%$ mountainous, and $0.5 \%$ steep (Santos et al., 2017).
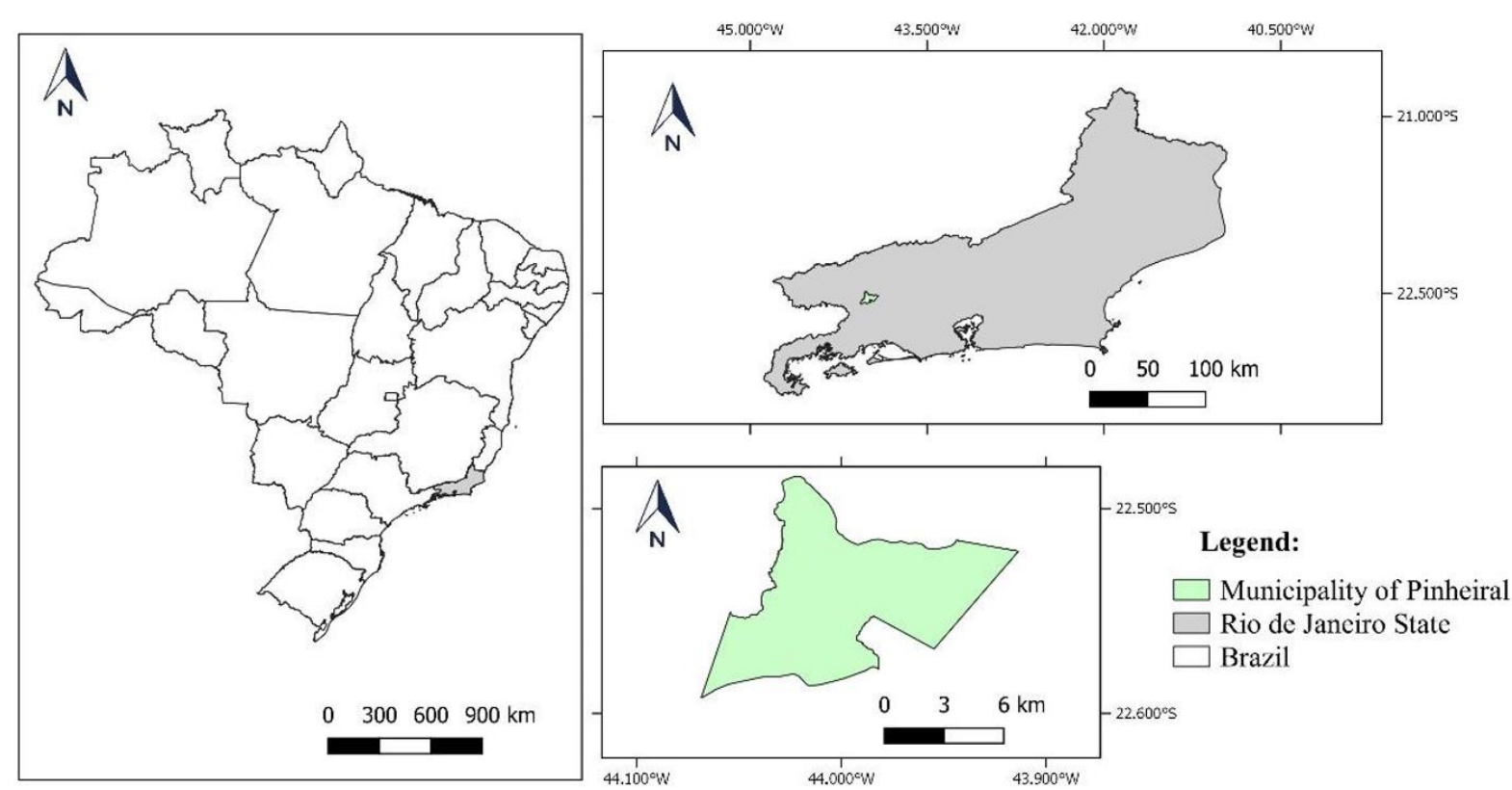

Figure 1. Study area map, municipality of Pinheiral - RJ, Brazil.

The current soil coverage of the region is composed by pastures, both managed (mainly Brachiari sp.) and non-managed (molasses grass - Melinis minutiflora, Hyparrhenia rufa, sapê, Imperata brasiliensis, Andropogon bicornis; bahia grass - Paspalum notatum, other grasses; and six native legumes). These pastures are in various stages of degradation, level of use and/or abandonment, and give rise to other forms of vegetation in the area, such as shrubby pastures and shrubs. The distribution of land in the sub-basin is distinct in its different portions of the slopes, with a predominance of large (over $150 \mathrm{ha}$ ) and medium properties on its upper and middle thirds, where the main activities are dairy farming and cattle breeding.

In the entire region of the Médio Vale of the Paraíba do Sul River, the first type of use was extractivism, which was subsequently replaced by coffee cultivation in the colonial period. Progressively, the coffee plantations were replaced by livestock farming, and inadequate management has contributed to the formation of the landscape that dominates the region today. The remaining forest fragments are small and located on the interfluves of the main hydrographic basins and in areas that are difficult to access, whose relief has prevented agricultural use.

Four gullies were selected (Figure 2), which were previously classified based on their stage of formation (initial, juvenile, mature, and senile) as described by Oka-Fiori and Soares (1976) and Dobek et al. (2011), from Google Earth images, and validated through field trips. The initial stage (IG) gully has channels and the bed has an irregular profile with a "V" cross-section and rectilinear walls, without ramifications. The juvenile stage (JG) gully has been subjected to a more intense erosive process with the formation of ducts, causing elongation, broadening, and deepening of the main channel. The mature gully (MG) has ramifications with jagged lines and a "U" cross section, with movement of earth on the walls, enlargement, vertical erosion in the ramifications, development of vegetation (grasses) at the bottom and consolidation of erosive processes in the channel. Finally, the senile gully (SG) presents a "U" cross section, a slightly irregular contour line, smooth sloping walls, vegetation cover, predominantly Embaúba (Cecropia sp.), grasses, and bamboo (Phyllostachys sp.) throughout the area, and a bed covered with alluvial deposits. Three areas were selected next to the gullies, one area under secondary 
forest (SF), one area under initial regeneration pasture (ISR), and one area under regeneration in the medium stage (MSR), which was adopted as a reference. In all study areas, the soil was identified as Latossolo Vermelho-Amarelo (Oxisol).

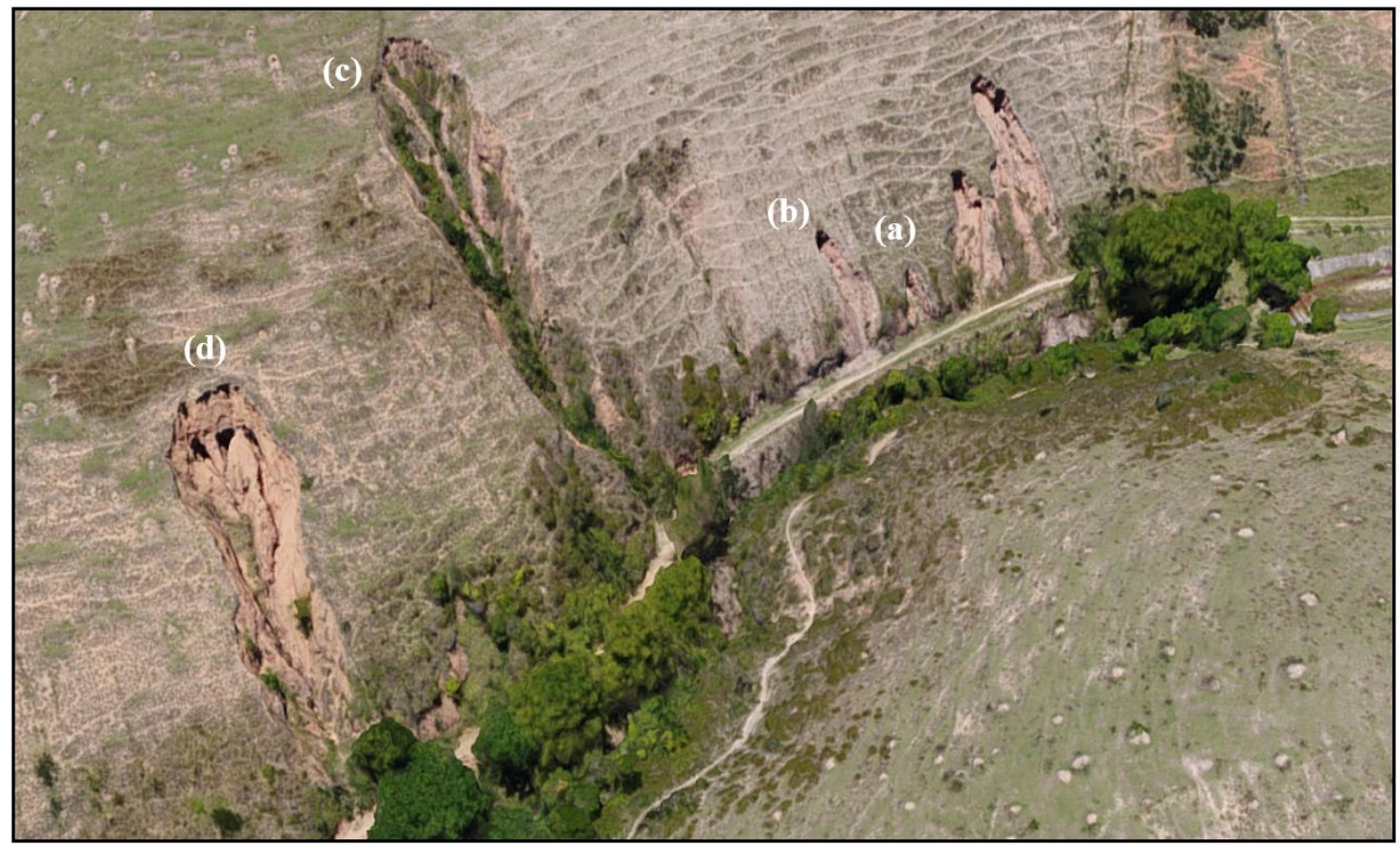

Figure 2. Gullies in different stages of formation. (a) Gully in the initial stage; (b) gully in the juvenile stage; (c) gully in the senile stage; (d) gully in the mature stage.

Source: Gaia-Gomes et al. (2020) adapted.

To evaluate the chemical, physical, and microbiological attributes of the soil, samples were collected at the $0-5 \mathrm{~cm}$ depth in two distinct seasons (end of the rainy season and dry season) in each gully and in the SF, MSR, and ISR areas. The samples were collected within the gullies in an irregular grid covering its extension. For SF, PRI, and PRM, $20 \times 20 \mathrm{~m}$ plots were selected in each area, and 16 simple samples were collected to make four composite soil samples.

Physical analysis (granulometry), chemical analysis ( $\mathrm{pH}, \mathrm{Ca}, \mathrm{Mg}, \mathrm{Ca}, \mathrm{P}, \mathrm{H}+\mathrm{Al}, \mathrm{K}, \mathrm{N}$ ), and soil organic carbon determination were performed according to Teixeira et al. (2017). Oxidizable carbon (POXC) was evaluated with the use of permanganate as described by Weil et al. (2003).

To assess enzyme activity, collected samples were stored at $4{ }^{\circ} \mathrm{C}$ until processing. Activities of $\beta$-glucosidase and acid phosphatase were assessed according to the method described by Eivazi and Tabatabai (1988); and fluorescein diacetate (FDA) hydrolysis as describe by Schnürer and Rosswal (1982).

Total soil microbial activity was quantified immediately after sampling using the basal soil respiration method, as described by Jenkinson and Powlson (1976), while the microbial biomass carbon (MBC) was assessed via fumigation-incubation as described by Vance et al. (1987) and Tate et al. (1988); microbial biomass nitrogen (MBN) was determined as described by Brookes et al. (1985).

Glomalin-related soil protein (GRSP; easily extractable-GRSP and total-GRSP) was extracted from the samples as described by Wright and Updahyaya (1998). GRSP-easily extractable fractions (EE-GRSP) were obtained via autoclave extraction using $20 \mathrm{mM}$ sodium citrate solution, $\mathrm{pH} \mathrm{7.4}$, at a temperature of $121^{\circ} \mathrm{C}$ for $30 \mathrm{~min}$. The total-GRSP fraction (TGRSP) was obtained using $50 \mathrm{mM}$ sodium citrate, $\mathrm{pH} 8.0$, at $121^{\circ} \mathrm{C}$, for $60 \mathrm{~min}$. When necessary, more than one autoclave cycle was performed to extract this fraction until samples 
were light-yellow in color. Both fractions were quantified by the Bradford method (1976) modified by Wright et al. (1996).

\subsection{Statistical analysis}

The results were analyzed by Lilliefors test for normality (test of Lillifors/ STATISTIC 8.0) and homogeneity of variances (Levene/STATISTIC 8.0). When this premise was met, the averages were compared by the Bonferroni t parametric test and, when this did not occur, the means were compared by the non-parametric Kruskall Wallis test $(\mathrm{P}<5 \%)$. To better understand the different environmental quality conditions of the study units, some parameters of each study unit were selected for multivariate statistical analysis by way of principal component analysis (PCA) and clustering (Paired group; Similarity measure: Gower), in addition to a correlation analysis with the PAST statistical program. For these analyses, the variables were grouped according to the number of replicates used for the statistical analysis (ANOVA and means test).

\section{RESULTS AND DISCUSSION}

There was no significant difference in the levels of clay and sand (coarse and total) in gullies at different formation stages (initial - IG; juvenile - JG; mature - MG; and senile - SG) and areas of secondary forest (SF), initial-stage regenerating pasture (PRI), and mediumregeneration stage pasture (MSR); however, variation was observed in the textural class ( $\mathrm{SF}$ clay-loam; ISR - sandy-loam; MSR, IG, JG, MG, SG - sandy clay loam) (Table 1).

Higher levels of fine sand were observed in ISR, in contrast to SF, MSR, and SG. No differences were observed between the gullies, nor between the SF and MSR areas. The highest levels of silt were observed in the SF and differed only from those in MSR and IG. Variable silt plus fine sand, an indicator of soil erodibility (Silva et al., 2003), was higher in SF and ISR, differing from MSR and IG, indicating that these fractions were removed by the erosive process in the latter two areas. This may be because superficial and subsurface water flow is more intense during the initial stage of gully formation. The other gullies (JG, MG, SG) presented intermediate values of silt plus fine sand (Table 1).

Table 1. Soil granulometric analysis in gullies at different formation stages (IG - initial; JG - juvenile; MG - mature; SG - senile), secondary forest (SF), mid-stage regeneration pasture (MSR), and initial-stage regeneration (ISR), at a depth of 0-0.05 m, in Pinheiral (RJ).

\begin{tabular}{|c|c|c|c|c|c|c|c|}
\hline \multirow{2}{*}{ Areas } & \multicolumn{3}{|c|}{ Sand } & \multirow{2}{*}{ Clay } & \multirow{2}{*}{ Silt } & \multirow{2}{*}{ Silt + Thin sand } & \multirow{2}{*}{ Textural class } \\
\hline & Thin & Coarse & Total & & & & \\
\hline & & & & $\mathrm{g} \mathrm{kg}^{-1}$ & & & \\
\hline SF & $129 \mathrm{~b}$ & $283 a$ & $412 \mathrm{a}$ & $283 \mathrm{a}$ & $304 \mathrm{a}$ & $434 \mathrm{a}$ & Clay-loam \\
\hline MSR & $106 \mathrm{~b}$ & $427 \mathrm{a}$ & $533 \mathrm{a}$ & $279 \mathrm{a}$ & $188 \mathrm{~b}$ & $294 \mathrm{~b}$ & Sandy clay loam \\
\hline ISR & $179 \mathrm{a}$ & $418 \mathrm{a}$ & $597 \mathrm{a}$ & $185 \mathrm{a}$ & $217 \mathrm{ab}$ & $397 \mathrm{a}$ & Sandy-loam \\
\hline IG & $141 \mathrm{ab}$ & $506 \mathrm{a}$ & $647 \mathrm{a}$ & $202 \mathrm{a}$ & $151 \mathrm{~b}$ & $292 \mathrm{~b}$ & Sandy clay loam \\
\hline JG & $144 \mathrm{ab}$ & $403 \mathrm{a}$ & $547 \mathrm{a}$ & $238 \mathrm{a}$ & $212 a b$ & $359 a b$ & Sandy clay loam \\
\hline MG & $131 \mathrm{ab}$ & $323 \mathrm{a}$ & $454 \mathrm{a}$ & $328 \mathrm{a}$ & $218 \mathrm{ab}$ & $349 a b$ & Sandy clay loam \\
\hline SG & $109 \mathrm{~b}$ & $387 \mathrm{a}$ & $496 \mathrm{a}$ & $295 \mathrm{a}$ & $208 \mathrm{ab}$ & 317 & Sandy clay loam \\
\hline
\end{tabular}

Means followed by equal letters in the column do not differ by the Bonferroni T or Kruskall Wallis test at $5 \%$. 
In relation to soil chemical attributes, the $\mathrm{pH}$ was lowest in the SF areas (dry season and rainy season) compared with the gullies and the pasture (MSR and ISR) (Table 2). This pattern can be explained by the greater deposition of plant litter in the SF area when compared with the gullies and pasture. This leads to a higher rate of decomposition and the release of high levels of acid, which reduces the soil $\mathrm{pH}$. Rukshana et al. (2011) reported that decomposing organic matter, depending on its chemical nature, can provide $\mathrm{H}^{+}$, which acidifies the soil.

Table 2. Chemical attributes and soil organic carbon in gullies at different formation stages (IG - initial; JG - juvenile; MG - mature; SG - senile), secondary forest (SF), mid-stage regeneration pasture (MSR), and initial-stage regeneration (ISR), at a depth of 0-0.05 $\mathrm{m}$ in two seasons (rainy season; dry season), in Pinheiral (RJ).

\begin{tabular}{|c|c|c|c|c|c|c|c|c|c|c|}
\hline \multirow{3}{*}{ Areas } & \multicolumn{2}{|c|}{$\mathrm{pH}$} & \multicolumn{2}{|c|}{$\mathrm{Ca}$} & \multicolumn{2}{|c|}{$\mathrm{Mg}$} & \multicolumn{2}{|c|}{$\mathrm{Al}$} & \multicolumn{2}{|c|}{$\mathrm{H}+\mathrm{Al}$} \\
\hline & \multirow[b]{2}{*}{ Rainy } & \multirow[b]{2}{*}{ Dry } & \multicolumn{8}{|c|}{$\mathrm{cmol}_{\mathrm{c}} \mathrm{Kg}^{-1}$} \\
\hline & & & Rainy & Dry & Rainy & Dry & Rainy & Dry & Rainy & Dry \\
\hline SF & $4.06 b^{*}$ & $3.68 \mathrm{c}$ & $0.75 \mathrm{~b}$ & $1.00 \mathrm{ab}^{*}$ & $0.42 \mathrm{a}$ & $1.27 \mathrm{ab}^{*}$ & $2.36 \mathrm{a}^{*}$ & $1.68 \mathrm{ab}$ & $8.95 \mathrm{a}$ & $9.98 \mathrm{a}$ \\
\hline MSR & $4.41 \mathrm{a}^{*}$ & $4.10 \mathrm{~b}$ & $1.32 \mathrm{a}$ & $1.17 \mathrm{a}^{*}$ & $0.50 \mathrm{a}$ & $0.85 b^{*}$ & $2.18 \mathrm{ab}$ & $2.23 \mathrm{a}$ & $8.70 \mathrm{a}$ & $11.11 \mathrm{a}^{*}$ \\
\hline ISR & $4.57 \mathrm{a}$ & $4.59 \mathrm{a}$ & $0.67 \mathrm{bc}$ & $1.07 \mathrm{ab}^{*}$ & $0.62 \mathrm{a}$ & $1.50 \mathrm{a}^{*}$ & $1.05 b^{*}$ & $0.50 \mathrm{~b}$ & $5.16 \mathrm{~b}$ & $5.53 \mathrm{~b}$ \\
\hline IG & $4.55 \mathrm{a}^{*}$ & $4.30 \mathrm{~b}$ & $0.40 \mathrm{~d}$ & $0.65 \mathrm{~cd}^{*}$ & $0.62 \mathrm{a}$ & $0.95 b^{*}$ & $1.19 \mathrm{ab}$ & $1.40 \mathrm{ab}$ & $3.88 \mathrm{~b}$ & $4.29 \mathrm{~b}$ \\
\hline JG & $4.38 \mathrm{a}$ & $4.31 \mathrm{~b}$ & $0.47 \mathrm{~cd}$ & $0.63 \mathrm{~cd}^{*}$ & $0.60 \mathrm{a}$ & $1.00 b^{*}$ & $1.53 \mathrm{ab}$ & $1.60 \mathrm{ab}$ & $4.83 \mathrm{~b}$ & $5.28 \mathrm{~b}$ \\
\hline MG & $4.52 \mathrm{a}^{*}$ & $4.28 \mathrm{~b}$ & $0.47 \mathrm{~cd}$ & $0.60 \mathrm{~d}$ & $0.60 \mathrm{a}$ & 0.97 b* & $1.55 \mathrm{ab}$ & $1.52 \mathrm{ab}$ & $4.66 \mathrm{~b}$ & $5.86 b^{*}$ \\
\hline SG & $4.49 \mathrm{a}^{*}$ & $4.21 \mathrm{~b}$ & $0.90 \mathrm{~b}$ & $0.87 \mathrm{bc}$ & $0.77 \mathrm{a}$ & $1.20 \mathrm{ab}^{*}$ & $1.50 \mathrm{ab}$ & $1.52 \mathrm{ab}$ & $4.46 \mathrm{~b}$ & $5.73 b^{*}$ \\
\hline \multirow{3}{*}{ Areas } & \multicolumn{2}{|c|}{$\mathrm{P}$} & \multicolumn{2}{|c|}{$\mathrm{K}$} & \multicolumn{2}{|c|}{$\mathrm{N}$} & \multicolumn{2}{|c|}{ TOC } & \multicolumn{2}{|c|}{ POXC } \\
\hline & \multicolumn{4}{|c|}{$\mathrm{mg} \mathrm{L}^{-1}$} & \multicolumn{6}{|c|}{$\mathrm{g} \mathrm{kg}^{-1}$} \\
\hline & Rainy & Dry & Rainy & Dry & Rainy & Dry & Rainy & Dry & Rainy & Dry \\
\hline SF & $7.94 \mathrm{a}^{*}$ & $1.17 \mathrm{~b}$ & $2.07 \mathrm{a}$ & $8.20 \mathrm{ab}^{*}$ & $2.65 \mathrm{a}^{*}$ & $1.53 \mathrm{a}$ & $29.21 \mathrm{ab}$ & $38.00 \mathrm{a}$ & $0.68 \mathrm{a}$ & $0.57 \mathrm{a}$ \\
\hline MSR & $6.92 \mathrm{ab}^{*}$ & $2.33 \mathrm{a}$ & $2.23 \mathrm{a}$ & $6.70 b^{*}$ & $2.42 \mathrm{ab}^{*}$ & $1.13 \mathrm{~b}$ & $30.58 \mathrm{a}$ & $24.28 \mathrm{ab}$ & $0.63 a b^{*}$ & $0.54 \mathrm{a}$ \\
\hline ISR & $6.43 a^{*}$ & $2.43 \mathrm{ab}$ & $2.17 \mathrm{a}$ & $11.75 \mathrm{a}^{*}$ & $1.58 b^{*} *$ & $0.70 \mathrm{c}$ & $21.24 \mathrm{abc}$ & $17.76 \mathrm{ab}$ & $0.44 \mathrm{abc}$ & $0.39 \mathrm{ab}$ \\
\hline IG & $6.33 \mathrm{ab}^{*}$ & $1.15 \mathrm{~b}$ & $2.22 \mathrm{a}$ & $6.23 \mathrm{~b}^{*}$ & $1.14 \mathrm{c}^{*}$ & $0.26 \mathrm{~d}$ & $5.91 \mathrm{bc}$ & $5.95 \mathrm{~b}$ & $0.36 \mathrm{abc} *$ & $0.18 \mathrm{~b}$ \\
\hline JG & $6.38 \mathrm{ab}^{*}$ & $1.47 \mathrm{ab}$ & $1.27 \mathrm{~b}$ & $5.30 \mathrm{~b}^{*}$ & $1.15 \mathrm{c}^{*}$ & $0.39 \mathrm{~cd}$ & $12.51 \mathrm{abc}$ & $10.07 \mathrm{ab}$ & $0.27 \mathrm{c}$ & $0.31 \mathrm{ab}$ \\
\hline MG & $6.26 \mathrm{~b}^{*}$ & $1.84 \mathrm{ab}$ & $1.03 \mathrm{~b}$ & $4.37 \mathrm{~b}^{*}$ & $0.89 \mathrm{c}^{*}$ & $0.48 \mathrm{~cd}$ & $4.12 \mathrm{c}$ & $6.50 \mathrm{~b}$ & $0.26 \mathrm{bc}$ & $0.35 \mathrm{ab}$ \\
\hline SG & $6.40 \mathrm{ab}^{*}$ & $1.28 \mathrm{ab}$ & $2.33 \mathrm{a}$ & $11.07 \mathrm{a}^{*}$ & $1.02 \mathrm{c}$ & $0.59 \mathrm{~cd}$ & $16.95 \mathrm{abc}$ & $11.27 \mathrm{ab}$ & $0.49 \mathrm{abc}$ & $0.39 \mathrm{ab}$ \\
\hline
\end{tabular}

Means followed by equal letters in the column do not differ by the Bonferroni T or Kruskall Wallis test at $5 \%$.

* Indicates a significant difference between seasons by the Bonferroni T or Kruskall Wallis test at 5\%. TOC - Total organic matter; POXC - oxidizable carbono.

For $\mathrm{H}+\mathrm{Al}$ content, the gullies in the different formation stages followed the same pattern observed in the ISR, in both seasons (Table 2). For the Al, it was verified that the gullies presented intermediate values between the ISR area and the SF and MSR areas, with higher values in the last two areas (Table 2). Lower $\mathrm{pH}$ value in SF may have contributed to the increase in $\mathrm{Al}$ solubility.

The nutrients most affected by the erosive process were $\mathrm{Ca}, \mathrm{K}$, and $\mathrm{N}$, with the lowest values observed in gullies in the initial (IG) and intermediate (JG and MG) stages of formation (Table 2). In general, there was no difference in $\mathrm{Mg}$ and $\mathrm{P}$ content between the gullies and the SF and pasture areas (Table 2). No significant differences were observed between SG and the forest in relation to the nutrients $\mathrm{Ca}, \mathrm{Mg}, \mathrm{P}$ and $\mathrm{K}$. It can be inferred that this pattern is related to the process of erosion stabilization in the gully, due, among other factors, to colonization by plant species (spontaneous regeneration) throughout its extension (Figure 2c), thus promoting the addition of plant litter and organic matter and the incorporation and maintenance of soil nutrients. Vegetation influences erosion by reducing its intensity and improving the capacity of soil infiltration (Jianbo et al., 2018).

Gomide et al. (2011) noted that the reduced soil fertility in gullies was due to the decreased 
organic matter contents resulting from the removal of vegetation in these environments, thus leading to reduced cycling of nutrients and increased losses through leaching. This pattern was confirmed by the analysis of total organic carbon (TOC) and oxidizable carbon (POXC) in the study areas. There were high positive correlations $(\mathrm{r}=>0.75, \mathrm{p}<0.5)$ between TOC and Ca, $\mathrm{P}$ and $\mathrm{N}$ in the rainy season. Significant decreases in TOC (approximately $80 \%$ in IG) and POXC (approximately 67\% in IG) were observed in gullies in the initial and mature stages (environments in which larger reductions in nutrient levels were observed) compared with pasture and/or SF areas. POXC is a labile fraction of organic carbon that is sensitive to soil use and management. It is highly informative for total soil organic matter, nutrients, soil structure, and microbial pools and activity; parameters commonly used as indicators of soil function, such as $\mathrm{C}$ sequestration, nutrient cycling, formation of soil structure, and biodiversity (Bongiorno et al., 2019).

In the senile stage gully, with natural regeneration occupying its entire extension, TOC and POXC levels were observed that were statistically similar the reference areas (SF, MSR, and ISR). Although TOC values below those in the reference areas were observed, especially in relation to SF and MSR, TOC was approximately $180 \%$ higher in IG. Shi et al. (2019) noted that the restoration of vegetation promotes the addition of plant litter and increases the amounts of small roots, which results in the addition of higher levels of carbon to the soil. In addition, it can improve soil infiltration and reduce runoff and sediment transport, which reduces TOC losses. According to Rumpel et al. (2018), plants, bacteria, fungi, and soil fauna, such as earthworms, contribute to the addition of organic matter and nutrients, which promote soil aggregation, making it resilient to erosion and increasing its retention capacity.

Regarding the influence of the sampling period on soil chemical attributes, there was greater variation in $\mathrm{pH}, \mathrm{Ca}, \mathrm{Mg}, \mathrm{P}, \mathrm{K}$, and $\mathrm{N}$. While high values for $\mathrm{pH}, \mathrm{P}$, and $\mathrm{N}$ were found in the rainy season, the highest levels of $\mathrm{Ca}, \mathrm{Mg}$, and $\mathrm{K}$ were generally recorded in the dry season. Of the evaluated organic matter fractions, the TOC did not vary between seasons in the reference areas and in the gullies. On the other hand, higher POXC values were observed in the rainy season compared to the dry season in the MSR area and in the initial gully. Significant change in TOC content in response to climate change is usually difficult to detect in a short time. In contrast, POXC is considered a labile fraction of SOM, and therefore may have an advantage over the TOC in detecting differences due to variations in temperature and precipitation (Culman et al., 2012).

Changes in the microbiological attributes of the soil were observed across the gully formation stages (Table 3). Total enzyme activity, evaluated by fluorescein diacetate (FDA) hydrolysis, was $69 \%$ less in the mature stage gully, compared with the SF in the rainy season. In the dry season, there was a $90 \%$ reduction in gullies in the initial, juvenile, and mature formation stages. In the senile gully, during rainy and dry periods, FDA activity was intermediate (110.13 and $44.07 \mu$ gFluoresc $\mathrm{g}^{-1} \mathrm{SS}_{\text {hour }}{ }^{-1}$, respectively) between the reference areas (SF, MSR, IRS) (average $=154.05$ and $108.45 \mu$ gFluoresc ${ }^{-1} \mathrm{SS}_{\text {hour }}{ }^{-1}$, respectively) and the other gullies (IG, JG, MG) (average $=59.95$ and $9.21 \mu$ gFluoresc $\mathrm{g}^{-1} \mathrm{SS} \mathrm{hour}^{-1}$, respectively) (Table 3). A similar pattern was observed for acid phosphatase and B-glucosidase activity (Table 3). The reductions in acid phosphatase reached $77 \%$ in MG in the rainy season, and 62\% in IG in the dry season compared with that in the SF area. $\beta$-Glucosidase activity decreased by around 71 and $85 \%$ in IG in the rainy and dry seasons, respectively, compared with that in the SF.

Thus, the effect of erosion on soil enzymatic activity is more intense in gullies in the initial (IG) and intermediate (JG and MG) stages compared with those in the senile stage (SG). This is possibly related to greater stability of erosive processes in SG, in addition to the positive effect of natural regeneration on enzymatic activity in SG. Silva et al. (2018) emphasized that the quantity and the quality of substrate added to the soil was important for increasing 
enzymatic activity. This allows for greater incorporation of organic matter, soil protection (physical barrier) against erosive processes, and increased stimulation of microbial activity. The enzymatic activity has been considered a good indicator of soil quality, reflecting the degree of quality achieved by a solo in the rehabilitation process (Silva et al., 2018).

Table 3. Soil microbiological atributes in areas of gullies at different formation stages (IG - initial; JG - juvenile; MG - mature; SG - senile), secondary forest (SF), mid-stage regeneration pasture (MSR), and initial-stage regeneration (ISR), at a depth of 0-0.05 $\mathrm{m}$ in two seasons (rainy season, dry season), in Pinheiral (RJ).

\begin{tabular}{|c|c|c|c|c|c|c|c|c|}
\hline \multirow{3}{*}{ Areas } & \multicolumn{2}{|c|}{ FDA } & \multicolumn{2}{|c|}{ Acid phosphatase } & \multicolumn{2}{|c|}{$\beta$-Glucosidase } & \multicolumn{2}{|c|}{ BSR } \\
\hline & \multicolumn{2}{|c|}{$\mu$ gFluoresc $^{-1} \mathrm{SS}$ hour $^{-1}$} & \multicolumn{2}{|c|}{$\mu$ mols pNP g ${ }^{-1} \mathrm{SS}$ hour $^{-1}$} & \multicolumn{2}{|c|}{$\mu$ mols pNP g ${ }^{-1} \mathrm{SS}$ hour $^{-1}$} & \multicolumn{2}{|c|}{$\mathrm{mg} \mathrm{CO}_{2} \mathrm{~g}^{-1} \mathrm{SS} \mathrm{d}^{-1}$} \\
\hline & Rainy & Dry & Rainy & Dry & Rainy & Dry & Rainy & Dry \\
\hline SF & $159.80 \mathrm{a}^{*}$ & $115.81 \mathrm{a}$ & $7.19 \mathrm{a}^{*}$ & $5.33 \mathrm{a}$ & $4.96 \mathrm{a}$ & $6.04 \mathrm{a}$ & $9.47 \mathrm{a}$ & $12.40 \mathrm{a}$ \\
\hline MSR & $152.92 \mathrm{ab}^{*}$ & $119.05 \mathrm{a}$ & $5.67 \mathrm{ab}$ & $4.06 \mathrm{~b}$ & $4.48 \mathrm{ab}^{*}$ & $3.69 \mathrm{ab}$ & $7.74 \mathrm{a}$ & $8.45 \mathrm{abc}$ \\
\hline ISR & $149.43 \mathrm{ab}^{*}$ & $90.49 \mathrm{~b}$ & $4.15 \mathrm{ab}^{*}$ & $3.04 \mathrm{bcd}$ & $2.23 \mathrm{~cd}$ & $3.51 \mathrm{ab}^{*}$ & $9.39 \mathrm{a}$ & $11.51 \mathrm{ab}$ \\
\hline IG & $64.86 b^{*}$ & $10.90 \mathrm{~d}$ & $2.49 \mathrm{bc}$ & $2.03 \mathrm{~d}$ & $1.43 \mathrm{~d}$ & $0.92 \mathrm{~b}$ & $8.99 \mathrm{a}$ & $5.23 \mathrm{abc}$ \\
\hline $\mathrm{JG}$ & $66.37 b^{*}$ & $7.28 \mathrm{~d}$ & $4.15 \mathrm{ab}^{*}$ & $2.33 \mathrm{~cd}$ & $2.31 \mathrm{bcd}$ & $1.35 \mathrm{~b}$ & $8.32 \mathrm{a}$ & $6.65 \mathrm{abc}$ \\
\hline MG & $48.61 b^{*}$ & $9.46 \mathrm{~d}$ & $1.63 \mathrm{c}$ & $2.34 \mathrm{~cd}$ & $1.62 \mathrm{~cd}$ & $1.89 \mathrm{ab}$ & $4.37 \mathrm{a}$ & $4.45 c$ \\
\hline SG & $110.13 \mathrm{ab}^{*}$ & $44.07 \mathrm{c}$ & $2.63 \mathrm{ab}$ & $3.31 \mathrm{bc}$ & $3.66 \mathrm{abc}^{*}$ & $2.28 \mathrm{ab}$ & $11.76 \mathrm{a}^{*}$ & $6.73 \mathrm{abc}$ \\
\hline \multirow{3}{*}{ Areas } & \multicolumn{2}{|c|}{$\mathrm{MBC}$} & \multicolumn{2}{|c|}{$\mathrm{MBN}$} & \multicolumn{2}{|c|}{ EE-GRSP } & \multicolumn{2}{|c|}{ T-GRSP } \\
\hline & \multicolumn{2}{|c|}{$\mathrm{mg} \mathrm{Cmic} \mathrm{kg-1}$} & \multicolumn{2}{|c|}{ mg Nmic kg ${ }^{-1}$} & \multicolumn{4}{|c|}{$\mathrm{mg} \mathrm{g}^{-1}$ soil } \\
\hline & Rainy & Dry & Rainy & Dry & Rainy & Dry & Rainy & Dry \\
\hline SF & $211.04 \mathrm{a}$ & $536.65 \mathrm{a}^{*}$ & $211.04 \mathrm{a}$ & $536.65 \mathrm{a}^{*}$ & $0.94 \mathrm{ab}$ & $1.86 \mathrm{a}^{*}$ & $1.66 \mathrm{a}$ & $3.85 \mathrm{a}^{*}$ \\
\hline MSR & $111.89 \mathrm{ab}$ & $312.33 \mathrm{ab}^{*}$ & $111.89 \mathrm{ab}$ & $312.33 \mathrm{ab}^{*}$ & $1.38 \mathrm{a}$ & $1.01 \mathrm{ab}$ & $2.84 \mathrm{a}$ & $1.77 \mathrm{ab}$ \\
\hline ISR & $48.46 \mathrm{ab}$ & $121.67 \mathrm{ab}$ & $48.46 \mathrm{ab}$ & $121.67 \mathrm{ab}$ & $0.63 \mathrm{abc}$ & $0.60 \mathrm{ab}$ & $1.44 \mathrm{ab}$ & $1.03 \mathrm{ab}$ \\
\hline IG & $45.54 \mathrm{~b}$ & 79.29ab & $45.54 \mathrm{~b}$ & 79.29ab & $0.31 \mathrm{abc}$ & $0.20 \mathrm{~b}$ & $0.52 \mathrm{ab}$ & $0.22 \mathrm{~b}^{*}$ \\
\hline $\mathrm{JG}$ & $76.92 \mathrm{ab}$ & $52.31 \mathrm{~b}$ & $76.92 \mathrm{ab}$ & $52.31 \mathrm{~b}$ & $0.32 \mathrm{abc}$ & $0.22 \mathrm{~b}$ & $0.68 \mathrm{ab}$ & $0.31 \mathrm{~b}^{*}$ \\
\hline MG & $37.86 \mathrm{~b}$ & $67.13 \mathrm{ab}^{*}$ & $37.86 \mathrm{~b}$ & $67.13 \mathrm{ab}^{*}$ & $0.08 \mathrm{c}$ & $0.28 \mathrm{~b}$ & $0.16 \mathrm{~b}$ & $0.35 \mathrm{~b}$ \\
\hline SG & $66.74 \mathrm{ab}$ & $71.30 \mathrm{ab}$ & $66.74 \mathrm{ab}$ & $71.30 \mathrm{ab}$ & $0.19 b c$ & $0.42 \mathrm{ab}$ & $0.78 \mathrm{ab}$ & $0.79 \mathrm{ab}$ \\
\hline
\end{tabular}

Means followed by equal letters in the column do not differ by the Bonferroni T or Kruskall Wallis test at $5 \%$.

* Indicates a significant difference between seasons by the Bonferroni T or Kruskall Wallis test at 5\%. FDA - fluorescein diacetate hydrolysis; Basal soil respiration (BSR), microbial biomass carbon (MBC) and microbial biomass nitrogen $(\mathrm{MBN})$; EE-GRSP = Easily extractable - Glomalin-related soil protein; $\mathrm{T}=$ Total - Glomalin-related soil protein.

For all enzymes evaluated, there were strong positive correlations $(r>0.80, p<0.01)$ with TOC and POXC. In general, the soil enzyme activities are strongly related to the content of organic matter and MBC (Maurya et al., 2020; Tiwari et al., 2019; Yuan and Yue, 2012; Gispert et al., 2013). Positive correlations were found between MBC ( $\mathrm{r}>0.70, \mathrm{p}>0.02)$ and the enzymes FDA, acid phosphatase, and $\beta$-glucosidase in both seasons. Silva et al. (2012), evaluated carbon and soil enzyme activity in soils under native vegetation, pasture, and agriculture in Pinheiral (RJ), and reported a significant positive correlation between the $\beta$ glucosidase activity and the TOC of the soil; this pattern was confirmed in the present study. $\beta$ Glucosidase activity is fundamental for the release of nutrients from organic matter, acting in the early stages of degradation of organic compounds, reducing molecular size and producing smaller organic structures (Tiwari et al., 2019; Tabatabai, 1994). $\beta$-Glucosidase activity has been used to evaluate soil quality under different management practices (Bhattacharyya et al., 2021; Tiwari et al., 2019).

Regarding the effect of the sampling period, FDA activity was higher in the rainy season compared with the dry season in all study units. Acid phosphatase activity varied between 
seasons in the reference areas (SF and ISR) and in JG, with higher activity observed in the rainy season. Variation in $\beta$-glucosidase activity was found in the MSR and SJ area, with higher activity in the rainy season, and ISR with higher activity in the dry season. Some studies have demonstrated that enzyme activity is also regulated by temperature, precipitation, and soil moisture content (Yang et al., 2017; Kittredge et al., 2018).

Basal soil respiration (BSR), indicative of total microbial activity, did not vary between the gullies and reference areas during the rainy season (Table 3), while in the dry season, sediment production decreased the BSR by around $60 \%$ in the MG compared with the SF. The carbon (MBC) of soil microbial biomass was higher in the SF area compared with IG and MG in the rainy season, and JG in the dry season (Table 3). The nitrogen (MBN) of soil microbial biomass was higher in the SF area compared with IG and MG in the rainy season (Table 3). This can be explained by the higher intake of plant material in this area, providing greater soil coverage. This results in the accumulation of more organic material and nutrients (Table 2) for development of the microbial community (Alves et al., 2011). In contrast, in the initial stage gully, the absence of vegetation (Figure 2) together with the low carbon content and $\mathrm{N}$ (Table 2) may have contributed to the lower values of $\mathrm{MBC}$ and $\mathrm{MBN}$ in both seasons.

Generally, similar MBC and MBN values were observed between the SF and the pasture areas (MSR and ISR) and the senile gullies (Table 3). In the pastures, the organic matter content and possible dense root mass may favor the presence of microbial biomass in the rhizosphere (Lopes et al., 2010). In the senile gully (SG), the presence of vegetation may improve the incorporation of carbon and nitrogen into microbial biomass, with minor losses by erosion.

No variations were observed in the levels of $\mathrm{MBC}, \mathrm{MBN}$, and basal soil respiration between the rainy and dry seasons in most study units (Table 3).

Regarding the glomalin-related soil protein, no significant differences were observed between areas, for both fractions (easily extractable and total) in the rainy season, except the MG, which presented values lower than SF and MSR (Table 3). In the dry season, the highest values of GRSP (EE and Total) were observed in the reference areas, followed by SG with intermediate values, and with lower values the other gullies (IG, JG and MG) (Table 3). Significantly reduced levels of GRSP were found in gullies at different stages of formation (IG, JG, MG) (Table 3), with a 94\% reduction in T-GRSP observed in the initial stage gully compared with the SF. This pattern could be related to the negative impact of erosion on AMF structures (hyphae and spores: structures that present glomalin in their composition). Conversely, higher values of GRSP in SF may be related to higher microbial activity, which may have impacted the rate of hyphae and arbuscular mycorrhizal fungi spore decomposition, and the consequent higher deposition of glomalin fractions. High correlations were observed between the GRSP fractions and variables related to soil microbial activity, such as the FDA (GRSP -T: $\mathrm{r}=0.84, \mathrm{p}=0.03$; GRSP -FE: $\mathrm{r}=0.81, \mathrm{p}=0.02$ ) (dry and rainy season) and BSR (GRSP -T: $\mathrm{r}=0.79, \mathrm{p}=0.03$; GRSP -FE: $\mathrm{r}=0.79, \mathrm{p}=0.03$ ) (dry season). According to Lutgen et al. (2003), the decomposition of hyphae should be considered for the increase in GRSP.

Positive and highly significant correlations were found between the GRSP and TOC fractions and N (GRSP -T: $r=0.98, p=0.00$; GRSP -FE: $r=0.96, p=0.00$ ) in soil in the dry season. GRSP is an important form of accumulated carbon and nitrogen in soil, since it contains high levels of these elements and is strongly correlated with soil aggregation (Sekaran et al., 2021). Thus, reductions in the soil content of this protein lead to reduced soil quality. Positive correlations between glomalin and carbon, nitrogen, and soil aggregation have been found in several studies, which assessed different conditions of soil use and management, as well as degraded areas and the recovery process (Sekaran et al., 2021; Liu et al., 2020; Dai et al., 2013).

No differences in GRSP were observed between the rainy and dry seasons in most study units (Table 3). Variations were observed only in SF, IG and JG. In the SF area, the highest GRSP levels (both fractions) were observed in the dry season, and in IG and JG, in the rainy 
season for T-GRSP fraction (Table 3). Nogueira et al. (2016) in a forest system in the Atlantic Forest biome observed a pattern similar to that of the present study for the EE-GRSP, whose contents were higher in the dry season compared to the rainy season. On the other hand, these authors, in the same area, observed that the T-GRSP was higher in the rainy season compared to the dry season, as observed in IG and JG. This shows that the dynamics of the GRSP fractions can vary depending on climate changes within the same environments, and also in different environments, as observed in the present study.

Based on dissimilarity between study units in terms of chemical attributes, total and oxidizable organic carbon, and the microbiological attributes of soils in gullies of different formation stages (IG, JG, MG, and SG) and the reference areas (SF, MSR, and ISR) in the rainy and dry seasons, a multivariate cluster analysis was performed (Figure 3). Three large distinct groups were formed in both seasons, which were separated at a maximum distance of about $58 \%$ in the rainy and dry seasons (Figure 3). In both seasons, a greater distance between SF $(58 \%)$ and the other study units was observed. In both rainy and dry seasons, greater similarity was observed between early, juvenile, and mature gullies, with a distance of up to $24 \%$ in the rainy season and $15 \%$ in the dry season, i.e. 76 and $85 \%$ similarity, respectively (Figure 3 a and $3 b)$.

The senile stage gully, in turn, formed a group with the ISR area during the rainy season, with a distance of $32 \%$ from the other gullies (Figure 3a). In the dry season, the distance between the SG and the other gullies was $25 \%$ (Figure $3 \mathrm{~b}$ ). Thus, SG is more differentiated from other gullies in relation to these soil attributes, which may be due to their format (" $U$ " cross section, slightly regular contour line, walls with gentle slope) and the presence of vegetation cover in its entire extension (Oka-Fiore and Soares, 1976).
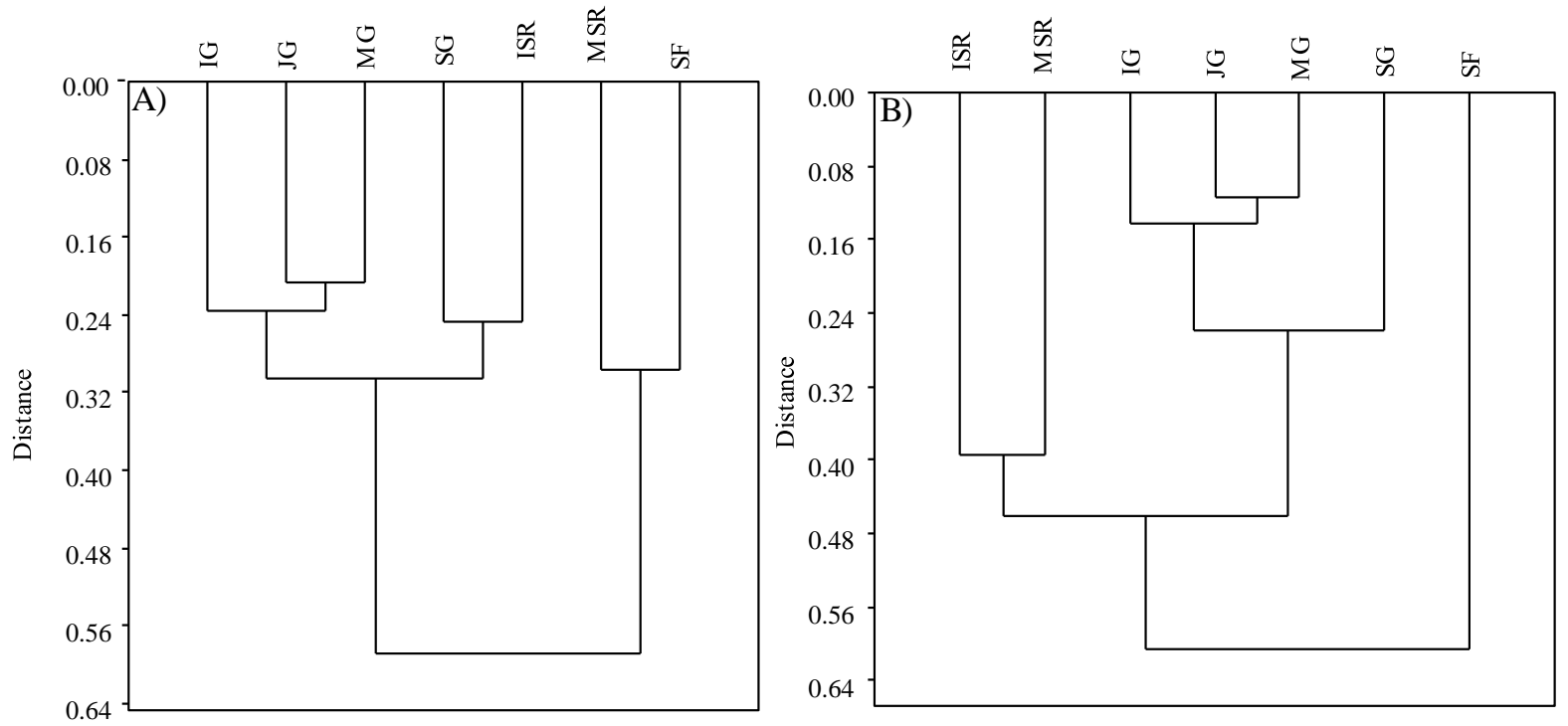

Figure 3. Dendrogram of cluster analysis integrating the chemical attributes, total organic carbon, oxidizable organic carbon, and the soil microbiological attributes of gullies in different stages of formation (IG - initial; JG - juvenile; MG - mature; SG - senile), secondary forest (SF), mid-stage regeneration pasture (MSR), and initial-stage regeneration (ISR), at a depth of 0-0.05 $\mathrm{m}$ in two seasons (rainy season - ch; dry season - sc), in Pinheiral (RJ).

Principal component analysis (PCA) revealed which variables contributed most to the grouping/separation of areas under study (Figure 4). Two main components for the chemical attributes, TOC and POXC, and the microbiological attributes (BSR, MBC, FDA, acid phosphatase, and $\beta$-glucosidase) of the soil were generated for both the rainy and dry seasons (Figure 4).

In the rainy season, the distribution of the selected variables showed an accumulated 
variance of $80.87 \%$ for axes 1 and 2; axis 1 was able to explain $63.80 \%$ and axis $2,17.07 \%$ of this variance (Figure 4a). In the dry season, the accumulated variance was $81.71 \%$ for axes 1 and 2. The first axis explained $62.90 \%$ and the second axis $18.81 \%$ of the variance (Figure $4 \mathrm{~b}$ ).

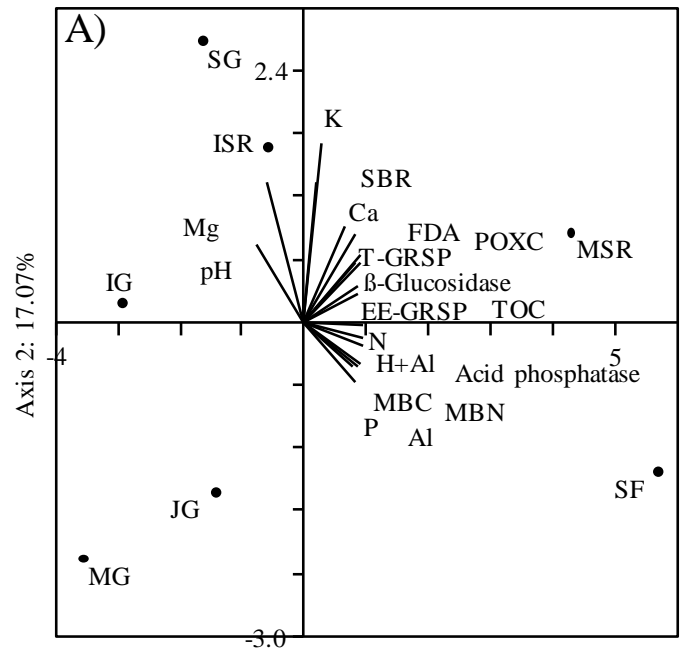

Axis 1: $63.80 \%$

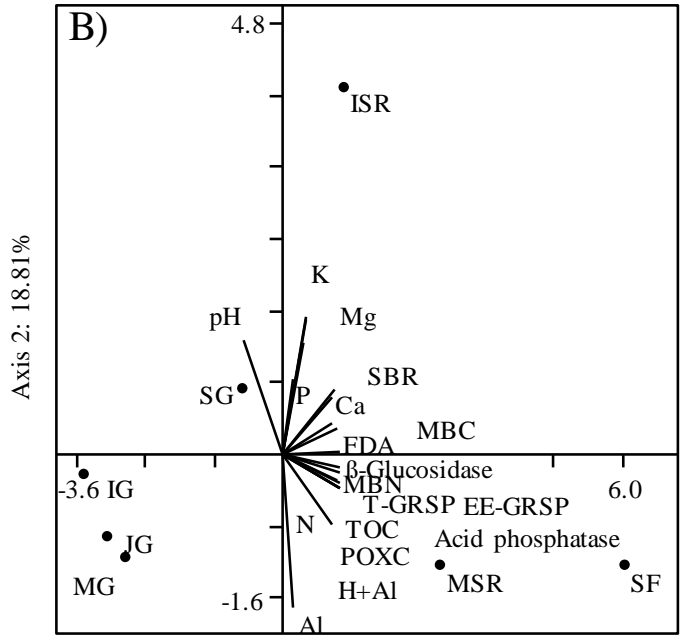

Axis 1: $62.90 \%$

Figure 4. Ordination diagram (A) rainy season; B) dry season; produced by principal component analysis of microbiological and chemical attributes of soil from gullies at different stages of formation (IG - initial; JI- juvenile; MG - mature, SG - senile), at a depth of 0-0.05 $\mathrm{m}$ in two seasons, in Pinheiral (RJ). MBC - microbial biomass carbon; MBN - microbial biomass nitrogen; BSR - basal soil respiration; T-GRSP - Total - glomalin-related soil protein; EE-GRSP - easily extractable - glomalin-related soil protein; FDA - fluorescein diacetate hydrolysis; TOC - total organic carbon; POXC - oxidizable carbon.

As shown in Figure 4a and 4b (rainy and dry seasons, respectively), the areas presented different separations. In the rainy season the gullies and pasture were arranged in the lower (JG and MG) and upper (ISR, SG, and IG) left quadrants, while the SF and MSR areas were arranged in the lower and upper right quadrants, respectively. Most variables were positively correlated $(r>0.70)$ with axis 1 , which was strongly related to the reference areas (MSR and $\mathrm{SF})$. In the dry season, the IG, JG, and MG formed a group in the lower left quadrant, while the pastures and SF were arranged on the opposite side, correlating with most of the analyzed variables; this represents the changes that occurred in the chemical and microbiological properties of the soil during erosion. SG was close to axis 0 , highlighting an intermediate pattern between the gullies in the earliest stages and the reference areas, suggesting that the rehabilitation of soil properties is more advanced.

PCA was used to evaluate the distribution of gullies at different formation stages (Figure 5) based on their chemical variables and the fractions of carbon and soil microbiological attributes evaluated in this study. During the rainy season, the distribution of the selected variables showed an accumulated variance of $76.01 \%$ for axes 1 and 2 ; axis 1 was able to explain $47.70 \%$ and axis 2, 28.31\% of variance (Figure 5a). In the dry season, the accumulated variance was $84.96 \%$ for axes 1 and 2 . The first axis explained $62.27 \%$ and the second explained $22.69 \%$ of the variance (Figure $5 \mathrm{~b}$ ). In both seasons, the senile stood out from the other gullies and was located in the lower right quadrant. Conversely, gullies IG, JG, and MG were generally located in the left upper and lower quadrants (Figure 5a, b). Axis 1 was responsible for the separation between gullies, while most variables were positively correlated $(r>0.70)$ with this axis as well as the senile gully (SG). Thus, one can observe that SG is more stable, and thus the microbiological and chemical attributes of the soil differ from those in gullies at previous stages. This is probably related to the development of dense vegetation in SG, enabling 
increased protection, soil carbon incorporation, and improved temperature and humidity conditions, which may stimulate the soil microbiota and the cycling of nutrients.

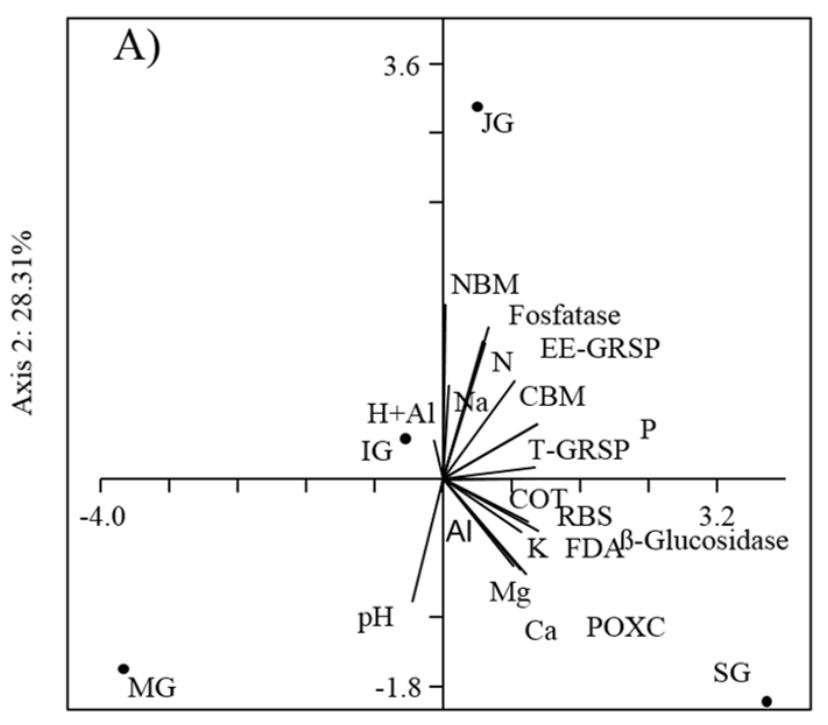

Axis 1: $47.70 \%$

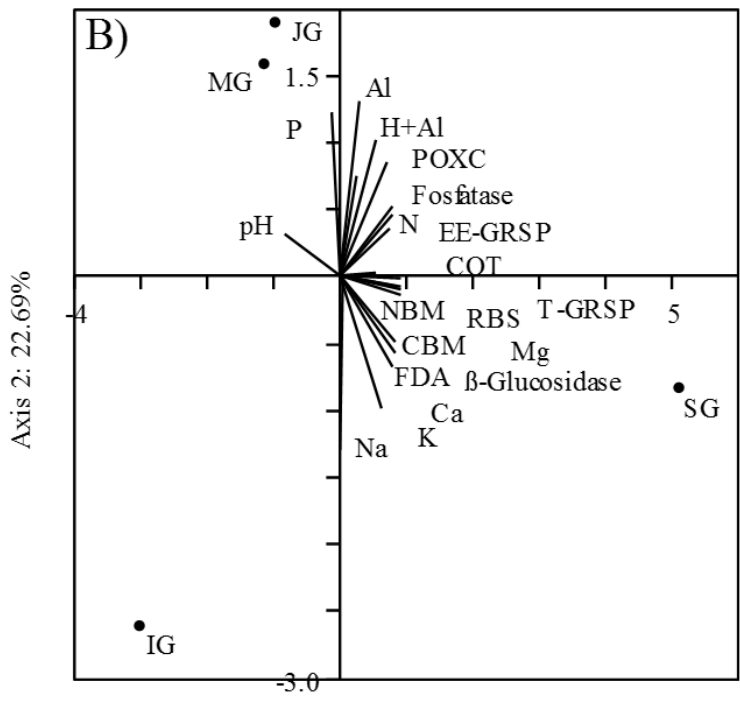

Axis 1: $62.27 \%$

Figure 5. Ordination diagram ( $\mathrm{a}$ - rainy season; b - dry season) produced by principal component analysis of microbiological and chemical attributes of soil from gullies at different stages of formation (IG - initial; JG - juvenile; MG - mature, SG - senile), at a depth of 0-0.05 $\mathrm{m}$ in two seasons, in Pinheiral (RJ). MBC - microbial biomass carbon; MBN - microbial biomass nitrogen; BSR - basal soil respiration; T- GRSP - Total - glomalin-related soil protein; EE- GRSP - easily extractable - glomalinrelated soil protein; FDA - fluorescein diacetate hydrolysis; TOC - total organic carbon; POXC oxidizable carbon.

\section{CONCLUSIONS}

Gullies in different stages of formation promote a decrease in soil fertility and modification of microbiological attributes, particularly when compared with secondary forest areas.

Using multivariate PCA, the microbiological and chemical attributes of the soil were discriminated between gullies with distinct formation stages. Stabilization of erosion in SG favors the regeneration of these attributes when compared with gullies in the initial (IG) and intermediate ( $\mathrm{JG}$ and $\mathrm{MG}$ ) formation stages.

The chemical attributes of total organic carbon; oxidizable organic carbon; FDA, $\beta$ glucosidase, and acid phosphatase activity; MBC and MBN; BSR; and GRSP are good indicators for evaluating erosion stabilization in gullies.

\section{ACKNOWLEDGEMENTS}

This work was supported by the CAPES - Coordenação de Aperfeiçoamento de Pessoal de Nível Superior 001 and FAPERJ - Fundação Carlos Chagas Filho de Amparo à Pesquisa do Estado do Rio de Janeiro.

\section{REFERENCES}

ALVES, T. S.; MATSUOKA, M.; CAMPOS, L. L.; ELIAS NETO, N.; LOUREIRO, M. F. Biomassa e atividade microbiana de solo sob vegetação nativa e diferentes sistemas de manejos. Acta Scientiarum Agronomy, v. 33, p. 341-347. 2011. http://dx.doi.org/10.4025/actasciagron.v33i2.4841 
BABUR, E.; DINDAROGLU, T. Seasonal changes of soil organic carbon and microbial biomass carbon in different forest ecosystems. In: UHER, I. (ed.). Environmental Factors Affecting Human Health. Londo: IntecOpen, 2020. p. 1-21. http://dx.doi.org/10.5772/intechopen.90656

BHATTACHARYYA, R.; RABBI, S. M. F.; ZHANG, Y.; YOUNG, I. M.; JONES, A. R. et al. Soil organic carbon is significantly associated with the pore geometry, microbial diversity and enzyme activity of the macro-aggregates under different land uses. Science $\begin{array}{lllll}\text { of the Total } & \text { Environment, } & \text { v. } & 778, & \end{array}$ http://dx.doi.org/10.1016/j.scitotenv.2021.146286

BONGIORNO, G.; BÜNEMANN, E. K.; OGUEJIOFOR, C. H.; MEIER, J.; GORT, G.; COMANS, R. et al. Sensitivity of labile carbon fractions to tillage and organic matter management and their potential as comprehensive soil quality indicators across pedoclimatic conditions in Europe. Ecological Indicators, v. 99, p. 38-50, 2019. http://dx.doi.org/10.1016/j.ecolind.2018.12.008

BRADFORD, M. M. Rapid and Sensitive Method for the Quantitation of Microgram Quantities of Protein Utilizing the Principle of Protein-Dye Binding. Analytical Biochemistry, v. 72, p. 248-254, 1976. http://dx.doi.org/10.1016/0003-2697(76)90527-3

BROOKES, P. C.; LANDMAN, A.; PRUDEN, G.; JENKINSON, D. S. Chloroform fumigation and the release of soil nitrogen: A rapid direct extraction method to measure microbial biomass nitrogen in soil. Soil Biology and Biochemistry, v. 17, p. 837-842, 1985. http://dx.doi.org/10.1016/0038-0717(85)90144-0

CEIVAP. Diagnóstico da dos recursos hídricos. Resende: AGEVAP, 2006. 194 p. Available at: https://www.ceivap.org.br/downloads/PSR-006-R0.pdf Access: 2021 Apr. 08.

CULMAN, S. W.; SNAPP, S. S.; FREEMAN, M. A.; SCHIPANSKI, M. E.; BENISTON, J. et al. Permanganate oxidizable carbon reflects a processed soil fraction that is sensitive to management. Soil Science Society of American Journal, v. 76, p. 494-504, 2012. https://doi.org/10.2136/sssaj2011.0286

DAI, J.; HU, J.; LIN, X.; IANG, A.; WANG, R.; ZHANG, J. et al. Arbuscular mycorrhizal fungal diversity, external mycelium length, and glomalin-related soil protein content in response to long-term fertilizer management. Journal of Soils and Sediments, v. 13, p. 1-11, 2013. http://dx.doi.org/10.1007/s11368-012-0576-Z

DOBEK, K.; DEMCZUK, P.; RODZIK, J.; HOŁUB, B. Types of gullies and conditions of their development in silvicultural loess catchment (Szczebrzeszyn Roztocze region, SE Poland). Landform Analysis, v. 17, p. 39-42, 2011.

EIVAZI, F.; TABATABAI, M. A. Glucosidases and agalactosidases in soils. Soil Biology and Biochemistry, v. 20, p. 601-606, 1988. http://dx.doi.org/10.1016/0038-0717(88)901411

ELLIOT, D. R.; CAPORN, S. J. M.; NWAISHI, F.; NILSSON, R. H.; SEM, R. Bacterial and fungal communities in a degraded ombrotrophic peatland undergoing natural and managed re-vegetation. Plos One, v. 5, p. 1-20, 2015. http://dx.doi.org/10.1371/journal.pone.0124726 
GAIA-GOMES, J. H.; PEREIRA, M. G.; SANTOS, G. L.; DELGADO, R. C. Physical parameters of the cachimbal river sub-basin associated to landscape change in PinheiralRJ, Brazil. Bioscience Journal, v. 34, p. 268-278, 2018. http://dx.doi.org/10.14393/BJv34n2a2018-36959

GAIA-GOMES, J. H.; PEREIRA, M. G.; FRANCELINO, M. R.; LARANGEIRA, J. P. B. Physical and chemical attributes of soil on gully erosion in the Atlantic forest biome. Revista Ambiente \& Água, v. 15, 2020. https://doi.org/10.4136/ambi-agua.2459

GISPERT, M.; EMRAN, M.; PARDINI, G.; DONI, S.; CECCANTI, B. The impact of land management and abandonment on soil enzymatic activity, glomalin content and aggregate stability. Geoderma, v. 202, p. 51-61, 2013. http://dx.doi.org/10.1016/j.geoderma.2013.03.012

GOMIDE, P. H. O.; SILVA, M. L. N.; SOARES, R. F. S. S. Atributos físicos, químicos e biológicos do solo em ambientes de voçorocas no município de Lavras, MG. Revista Brasileira de Ciência do Solo, v. 35, p. 567-577, 2011. http://dx.doi.org/10.1590/S010006832011000200026

HASHIM, Z. E.; ALZUBAIDI, L. A.; AL-MADHHACHI, A. T. The Influence of Microbiology on Soil Aggregation Stability. IOP Conference Series: Materials Science and Engineering, v. 870, 2020. http://dx.doi.org/10.1088/1757-899X/870/1/012110

JENKINSON, D. S.; POWLSON, D. S. The effects of biocidal treatments on metabolism in soil-I. Fumigation with chloroform. Soil Biology and Biochemistry, v. 8, p. 167-177, 1976. http://dx.doi.org/10.1016/0038-0717(76)90001-8

JIANBO, L.; GUANGYAO, G.; SHUAI, W.; LEI, J.; XING, W.; BOJIE, F. The effects of vegetation on runoff and soil loss: Multidimensional structure analysis and scale characteristics. Journal of Geographical Sciences, v. 28, p. 59-78, 2018. http://dx.doi.org/10.1007/s11442-018-1459-z

KITTREDGE, H. A.; CANNONE, T.; FUNK, J.; CHAPMAN, S. K. Soil respiration and extracellular enzyme production respond differently across seasons to elevated

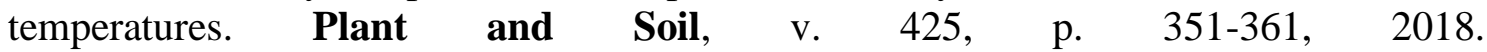
http://dx.doi.org/10.1007/s11104-018-3591-z

KÖPPEN, W. Das geographische system der klimate. Handbuch der klimatologie. Berlim: Borhtraeger, 1936.

LANDEROS-SÁNCHEZ, C.; MENDOZA-HERNÁNDEZ, J. H. R.; PALMA-LÓPEZ, D. Sustainability of agricultural production under irrigation. In: MASLOV, B. S. (ed.). Agricultural Land Improvement: Amelioration and Reclamation. Oxford: Eolss, 2009. v. 1. p. 338-340.

LIU, H.; WANG, X.; LIANG, C.; AI, Z.; WU, Y.; XU, H. et al. Glomalin-related soil protein affects soil aggregation and recovery of soil nutrient following natural revegetation on $\begin{array}{lllll}\text { the Loess } & \text { Plateau. } & \text { Geoderma, }\end{array}$ https://doi.org/10.1016/j.geoderma.2019.113921

LOPES, M. M.; SALVIANO, A. A. C.; ARAUJO, A. S. F. L.; NUNES, A. P. L.; OLIVEIRA, M. E. Changes in soil microbial biomass and activity in different Brazilian pastures. Spanish Journal of Agricultural Research, v. 8, p. 1253-1259, 2010. http://dx.doi.org/10.5424/sjar/2010084-1411 
LUTGEN, E. R.; MUIR-CLAIRMONT, D.; GRAHAM, J.; RILLIG, M. C. Seasonality of arbuscular mycorrhizal hyphae and glomalin in a western Montana grassland. Plant and Soil, v. 257, p. 271-83, 2003. http://dx.doi.org/10.1023/a:1026224209597

MACHADO, R. L.; RESENDE, A. S.; CAMPELLO, E. F. C; OLIVEIRA, J. A.; FRANCO, A. A. Soil and nutrient losses in erosion gullies at different degrees of restoration. Revista Brasileira de Ciência do Solo, v. 34, p. 945-954, 2010. http://dx.doi.org/10.1590/S010006832010000300036

MAURYA, S.; ABRAHAM, J. S.; SOMASUNDARAM, S.; TOTEJA, R.; GUPTA, R.; MAKHIJA, S. Indicators for assessment of soil quality: a mini-review. Environmental Monitoring and Assessment, v. 192, p. 604, 2020. http://dx.doi.org/10.1007/s10661020-08556-Z

MUCHANE, M. N.; PULLEMAN, M. M.; VANLAUWE, B.; JEFWA, J.; KUYPER, T. W. Impact of arbuscular mycorrhizal fungi and earthworms on soil aggregate stability, glomalin, and performance of pigeonpea, Cajanus cajan. Soil Research, v. 57, p. 53-65, 2018. http://dx.doi.org/10.1071/sr18096

NOGUEIRA, L. R.; SILVA, C. F. DA; PEREIRA, M. G.; GAIA-GOMES, J. H.; SILVA, E. M. R. Biological properties and organic matter dynamics of soil in pasture and natural regeneration areas in the atlantic forest biome. Revista brasileira de ciência do solo, $\mathrm{v}$. 40, 2016. http://dx.doi.org/10.1590/18069657rbcs20150366

OKA-FIORI, C.; SOARES, P. C. Aspectos evolutivos das voçorocas. Notícia Geomorfológica, v. 16, n. 3, p. 114-124, 1976.

PARIHAR, M.; RAKSHIT, A.; MEEN, V. S.; GUPTA, V. K.; RANA, K. et al. The potential of arbuscular mycorrhizal fungi in C cycling: a review. Archives of Microbiology, v. 202, p. 1581-1596, 2020. https://doi.org/10.1007/s00203-020-01915-x

RUKSHANA, F.; BUTTERLY, C.; BALDOCK, J. A.; TANG, C. Model organic compounds differ in their effects on $\mathrm{pH}$ changes of two soils differing in initial $\mathrm{pH}$. Biology and Fertility of Soils, v. 47, p. 51-62, 2011. http://dx.doi.org/10.1007/s00374-010-0498-0

RUMPEL, C.; AMIRASLANI, F.; KOUTIKA, L. S.; SMITH, P.; WHITEHEAD, D.; WOLLENBERG, E. Put more carbon in soils to meet Paris climate pledges. Nature, v. 564, p. 32-34, 2018. http://dx.doi.org/10.1038/d41586-018-07587-4

SANTOS, G. L.; PEREIRA, M. G.; DELGADO, R. C.; MORAES, L. F. D. Padrões da Regeneração Natural na Região de Mar de Morros, Pinheiral-RJ. Floresta e Ambiente, v. 24, 2017. http://dx.doi.org/10.1590/2179-8087.008115

SCHNÜRER, J.; ROSSWALL, T. Fluorescein diacetate hydrolysis as a measure of total microbial activity in soil and litter. Applied and Environmental Microbiology, v. 43, p. 1256-1261, 1982. https://doi.org/10.1128/aem.43.6.1256-1261.1982

SEKARAN, U.; SAGAR, K. L.; KUMAR, S. Soil aggregates, aggregate-associated carbon and nitrogen, and water retention as influenced by short and long-term no-till systems. Soil and Tillage Research, v. 208, 2021. https://dx.doi.org/10.1016/j.still.2020.104885

SHI, P.; ZHANG, Y.; LI, P.; LI, Z.; YU, K. et al. Distribution of soil organic carbon impacted by land-use changes in a hilly watershed of the Loess Plateau, China. Science of the Total Environment, v. 652, p. 505-512, 2019. https://doi.org/10.1016/j.scitotenv.2018.10.172 
SILVA, A. M.; SCHULZ, H. E.; CAMARGO, P. B. Erosão e hidrossedimentologia em bacias hidrográficas. São Carlos: Rima, 2003.

SILVA, C. P.; MENDE FILHO, P. F.; GOMES, V. F. F.; MARTINS, C. M.; CUNHA, C. S. M.; LOBATO, M. G. R. Glomalin-related soil protein content in areas of degraded and revegetated Caatinga in the municipality of Irauçuba. Journal of Agricultural Science,v. 10, p. 1-11, 2018. https://doi.org/10.5539/jas.v10n1p302

SILVA, C. F.; PEREIRA, M. G.; MIGUEL, D. L.; FEITORA, J. C. F.; LOSS, A. et al. Carbono orgânico total, biomassa microbiana e atividade enzimática do solo de áreas agrícolas, florestais e pastagem no médio vale do Paraíba do Sul (RJ). Revista Brasileira de Ciência do Solo, v. 36, p. 1680-1689, 2012. https://doi.org/10.1590/S010006832012000600002

SOS Mata Atlântica. Relatório anual de atividades 2017. Available at: https://www.sosma.org.br/wp-content/uploads/2018/10/AFRASOSMA2017web.pdf Access: 2018 Mar. 18.

TABATABAI, M. A. Soil enzymes. In: WEAVER, R. W.; ANGLE, J. S.; BOTTOMLEY, P. S. (Eds.). Methods of soil analysis: microbiological and biochemical properties. Madison: Soil Science Society of America, 1994. p. 775-883.

TATE, K. R.; ROSS, D. J.; FELTHAM, C. W. A direct extraction method to estimate soil microbial C: Effects of experimental variables and some different calibration procedures. Soil Biology and Biochemistry, v. 20, p. 329-335, 1988. https://doi.org/10.1016/00380717(88)90013-2

TEIXEIRA, P. C.; DONAGEMMA, G. K.; FONTANA, A.; TEIXEIRA, W. G. Manual de Métodos de Análise de Solo. Rio de Janeiro: Embrapa Solos, 2017.

TIWARI, R.; DWIVEDI, B. S.; SHARMA, Y. M.; SHARMA, A.; DWIVEDI, A. K. Activities of $\beta$-glucosidase, Phosphatase and Dehydrogenase as Soil Quality Indicators: A Review. International Journal of Current Microbiology and Applied Sciences, 8, 834-846, 2019. https://doi.org/10.20546/ijcmas.2019.806.101

VANCE, E. D.; BROOKES, P. C.; JENKINSON, D. S. Microbial biomass measurements in forest soils: the use of the chloroform fumigation-incubation method in strongly acid soils. Soil Biology and Biochemistry, v. 19, n. 6, p. 697-702, 1987. https://doi.org/10.1016/0038-0717(87)90051-4

VANWALLEGHEM, T.; POESEN, J.; NACHTERGAELE, J.; VERSTRAETEN, G. Characteristics, controlling factors and importance of deep gullies under cropland on

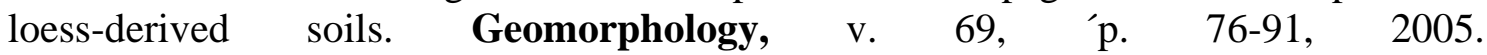
https://doi.org/10.1016/j.geomorph.2004.12.003

WANG, W.; ZHONG, Z.; WANG, Q.; WANG, H.; FU, Y.; HE, X. Glomalin contributed more to carbon, nutrients in deeper soils, and differently associated with climates and soil properties in vertical profiles. Scientific Reports, v. 7, 2017. https://doi.org/10.1038/s41598-017-12731-7

WEIL, R. R.; ISLAM, K. R.; STINE, M. A.; GRUVER, J. B., SAMSON-LIEBIG, S. E. Estimating active carbon for soil quality assessment: a simplified method for laboratory and field use. American Journal of Alternative Agriculture, v. 18, p. 3-17, 2003. https://doi.org/10.1079/AJAA2003003 
WRIGHT, S. F.; FRANKE-SNYDER, M.; MORTON, J. B.; UPADHYAYA, A. Time course study and partial characterization of a protein on hyphae of arbuscular mycorrhizal fungi during active colonization of roots. Plant and Soil, v. 181, p. 193-203, 1996. https://doi.org/10.1007/BF00012053

WRIGHT, S. F.; UPADHYAYA, A. A survey of soils for aggregate stability and glomalin, a glycoprotein produced by hyphae of arbuscular mycorrhizal fungi. Plant and Soil, v. 198, p. 97-107, 1988. https://doi.org/10.1023/A:1004347701584

YANG, K.; ZHU, J.; ZHANG, M.; YAN, Q.; SUN, O. J. Soil microbial biomass carbon and nitrogen in forest ecosystems of Northeast China: a comparison between natural secondary forest and larch plantation. Journal of Plant Ecology, v. 3, p. 175-182, 2010. https://doi.org/10.1093/jpe/rtq022

YANG, S.; ZHANG, Y.; CONG, J.; WANG, M.; ZHAO, M.; LU, H. et al. Variations of Soil Microbial Community Structures Beneath Broadleaved Forest Trees in Temperate and Subtropical Climate Zones. Frontiers in Microbiology, v. 8, p. 200, 2017. https://doi.org/10.3389/fmicb.2017.00200

YUAN, B. C.; YUE, D. X. Soil microbial and enzymatic activities across a chronosequence of Chinese pine plantation development on the Loess Plateau of China. Pedosphere, v. 22, p. 1-12, 2012. https://doi.org/10.1016/S1002-0160(11)60186-0

ZHOU, Z.; WANG, C.; LUO, Y. Effects of forest degradation on microbial communities and soil carbon cycling: A global meta-analysis. Global Ecology and Biogeography, v. 27, p. 110-124, 2018. https://doi.org/10.1111/geb.12663 